\title{
Biological and morphological aspects of Plectris aliena (Coleoptera: Melolonthidae) in sugarcane in Brazil
}

\author{
Elias Soares Gomes ${ }^{1}$; Crébio José Ávila² \& Mariana Alejandra Cherman³
}

${ }^{1}$ Universidade Federal da Grande Dourados (UFGD), Faculdade de Ciências Biológicas e Ambientais (FCBA), Programa de Pós-Graduação em Entomologia e Conservação da Biodiversidade (PPGECB). Dourados, MS, Brasil. ORCID: http://orcid.org/0000-0002-7401-3352. E-mail: eliasjv_gomes@hotmail.com

2 Empresa Brasileira de Pesquisa Agropecuária (EMBRAPA), Centro de Pesquisa Agropecuária do Oeste (CPA0). Dourados, MS, Brasil. ORCID: http://orcid.org/0000-0001-5829-7220.E-mail: crebio.avila@embrapa.br

3 Universidade Federal de Mato Grosso (UFMT), Instituto de Biociências (IB), Departamento de Biologia e Zoologia, Laboratório de Scarabaeidologia. Cuiabá, MT, Brasil. ORCID: http://orcid.org/0000-0001-6114-7290. E-mail: marianabioar@gmail.com

\begin{abstract}
Plectris aliena (Coleoptera, Melolonthidae) Chapin is a species already recorded causing serious damage to various cultures in North America and Australia. Although its occurrence has recently been reported in Brazil, information about its distribution, taxonomy, and biology is limited. Thus, this study aims to report this new occurrence of $P$. aliena in Deodápolis (Mato Grosso do Sul, Brazil), as well as to present bioecological and morphological aspects of this species. In this way, the seasonal distribution and the life cycle was studied in the years 2017 and 2018. The larvae were sampled through trenches made in the soil and reared in the laboratory. Adults were captured using "Luiz de Queiroz" light traps. Adults have body with dense white hairs, antennae with 10 antenomeres; they measure approximately $12 \mathrm{~mm}$ in length, and their antennal lamellae are larger for males than females. The larvae reach $30 \mathrm{~mm}$ in length in the third stage and pupae show about $19 \mathrm{~mm}$ in length. The life cycle of this species is univoltine. Due to the great diversity of Plectris and the scarce information available about this species in South America, this study will facilitate its identification in the field and indicate the best time for monitoring in sugarcane crop.
\end{abstract}

Keywords. Macrodactylini; Seasonal distribution; Taxonomy; Biology.

\section{INTRODUCTION}

Brazil is the world's largest producer of sugarcane, which has significant importance for the national economy, in production of alcohol and sugar (CONAB, 2020; Lucchesi, 1995). Ethanol production grew $24.5 \%$ in state of Mato Grosso do Sul in the 2018/2019 harvest, becoming the third largest Brazilian producer (CONAB, 2020). However, many factors reduce the productivity of this crop, with emphasis on the damage caused by soil pests (Arrigoni, 1999; Gallo et al., 2002).

Adult Melolonthidae beetles (sensu Endrödi, 1966 modified by Cherman \& Morón, 2014) usually feed on plant tissues, secretions, and plant remains, or they do not feed. However, their larvae known as white grubs ("coró" in Portuguese) can be saprophagous, rhizophagous, or xylophagous (Morón, 1997, 2004). Some species are considered beneficial due to their ability to transport and process organic matter in the soil profile, open- ing galleries, thus contributing to nutrient cycling and water flow (Gassen, 1999; Morón, 2004; Cherman et al., 2013). Although 1,008 species of Melolonthidae are registered in Brazil, less than $1 \%$ of these cause damage to crops (Morón, 2004). Potentially harmful species belong mainly to Cyclocephalini (Dynastinae), Geniatini (Rutelinae), Melolonthini, and Macrodactylini (Melolonthinae) tribes, whose larvae feed on plant roots (Morón, 2004; Ávila \& Santos, 2009; Santos \& Ávila, 2009). White grubs can attack newly planted sugarcane culms, basal internodes, and the root system (Pinto et al., 2009).

In the state of Mato Grosso do Sul, the main species of white grubs that occur in the no-tillage system are Liogenys suturalis Blanchard, Phyllophaga cuyabana Moser, and Paranomala testaceipennis Blanchard, which also cause damage to annual crops such as corn, soybeans, wheat and oats (Ávila \& Santos, 2009). Plectris LePeletier and Audinet-Serville species have been reported to cause damage to soybean and maize 
(Oliveira \& Hoffmann-Campo, 2001). Oliveira et al. (2004) and Oliveira \& Farias (2007) cited P. pexa Germar as a soil pest of soybean in northern Paraná state, Brazil. Morón \& Salvadori (2006) reported larvae of $P$. (= Demodema) brevitarsis (Blanchard) feeding on soybean roots, in the southern region of Brazil, while Valmorbida et al. (2018) found larvae of $P$. griseovestita Moser in natural pastures and cultivated areas in the Brazilian Pampa. In addition, Coutinho et al. [2020]. recorded P. aliena Chapin for the first time in South America, with this species having the potential to cause damage to sugarcane fields in the Midwest region of Brazil, in the municipality of Nova Andradina. Plectris aliena was found for the first time in lawns of Charleston, South Carolina, USA (Chapin, 1934a). Chapin (1934b) suggested that $P$. aliena is native to the northern region of South America because of the distribution of Plectris and other similar genera in this region. In North Carolina, producers estimated that P. aliena has already caused losses of more than US\$ 16 million, only for industry, because larvae of this species can consume up to $100 \%$ of the sweet potato (Ipomoea batatas L.) roots (Brill \& Abney, 2013). Brill et al. (2013) registered larvae of $P$. aliena associated with soybean (Glycine max L.), maize (Zea mays L.), cotton (Gossypium hirsutum L.), peanuts (Arachis hypogaea L.), and tobacco (Nicotiana tabacum L.) also in North Carolina, USA. Roberts (1968) reported larvae of this same species damaging pasture, while Samson et al. (2013) listed P. aliena as a pest harmful to sugarcane (Saccharum officinarum L.) (Poales: Poaceae), both in New South Wales, Australia.

Recently, high densities of white grubs were observed in sugarcane fields in the municipality of Deodápolis, Mato Grosso do Sul, Brazil. Due to the trend towards increased production of sugar and ethanol in the Midwest region of Brazil, $P$. aliena represents a threat to most states that produce sugarcane in the region, as mentioned by Coutinho et al. [2020].

Thus, this study aims to report the new occurrence of P. aliena in Deodápolis (Mato Grosso do Sul, Brazil), as well as to present bioecological and morphological aspects of this species.

\section{MATERIAL AND METHODS}

\section{Collection location}

This study was conducted in areas of sugarcane crop in the state of Mato Grosso do Sul, municipality of Deodápolis $\left(21^{\circ} 52^{\prime} \mathrm{S}\right.$ and $54^{\circ} 01^{\prime} \mathrm{W}$; $341 \mathrm{~m}$ alt.), Brazil. Sampling was carried out in three areas with 12,25 , and 29 ha, respectively, approximately $500 \mathrm{~m}$ apart, in soil characterized as Latossolo Vermelho (IBGE, 2019). The climate of this region corresponds to Aw, according to the Köppen classification, as hot-humid tropical environment, with rainy summer and dry winter (Alvares et al., 2013). The average annual temperature of Deodápolis is $23.1^{\circ} \mathrm{C}$, with an average rainfall of $1,563 \mathrm{~mm}$ (IBGE, 2019).

\section{Seasonal distribution of Plectris aliena in sugarcane}

From May 2017 to April 2018, soil sampling was performed and light traps were used to obtain P. aliena immatures and adults, respectively. The larvae and pupae of $P$. aliena were collected through trenches made in the soil, with $100 \mathrm{~cm}$ length, $100 \mathrm{~cm}$ width, and $\times 30 \mathrm{~cm}$ depth $(\times \times)$, carried out at 15-day intervals. On each sampling date, 10 trenches were opened between the sugarcane plants, aiming to quantify the number of larvae and pupae. The larvae collected in the field were kept in $500 \mathrm{ml}$ plastic containers with soil and sugarcane seedlings, which were replaced weekly. The larvae were maintained in these containers until the adult emergence.

Light traps model "Luiz de Queiróz", equipped with a 20-watt fluorescent lamp, were used from $6 \mathrm{pm}$ to $6 \mathrm{am}$, to collect $P$. aliena adults. A light trap was used for each collection event being performed 24 samplings over a year. Adults were identified using the entomological key for Plectris species (Frey, 1967), and confirmed by comparison with the primary type housed at the entomological collection of the United States Smithsonian National Museum of Natural history, Washington D.C., United States (USNM, ex-curator Manager Floyd Shokley). Larvae were identified using the key to Melolonthidae larvae of Cherman et al. (2013) and compared with the description of Böving (1936). Voucher specimens were deposited in the Coleção Entomológica Pe. J.S. Moure, Curitiba, Brazil (DZUP, Lúcia M. de Almeida). A digital caliper (accuracy of $0.05 \mathrm{~mm}$ ) was used to monitor larval growth and differentiation of the instars. The number of instars was determined using the Dyar rule (Parra \& Haddad, 1989).

\section{Morphological study of Plectris aliena and Statistical analysis}

Examination of immature and adult stages of $P$. aliena, was performed using ZEISS ${ }^{\circledR}$ STEMI SV6 microscope and ZEISS ${ }^{\circledR}$ optical microscope. The drawings were made using a coupled clear camera and a millimeter objective. Measurements of morphological characters (body length, body width, antennal club, metathoracic claws, and metatarsomeres) between the sexes were subjected to the analysis of variance. When significant effect of treatment was found, the means were compared by Student's T test for independent samples. The analyses were performed using the statistical program SAS (Statistical Analysis System, Version 9.1), and the normality of the data assessed by the Cochran test.

\section{RESULTS}

The presence of $P$. aliena was recorded in all samples of immatures and adults examined in the study, together with a few larvae of the following genera: Leucothyreus Macleay, Cyclocephala Dejean and Phyllophaga Harris. In total, 240 trenches were opened in the soil during the sampling period, being found immatures of P. aliena: 950 


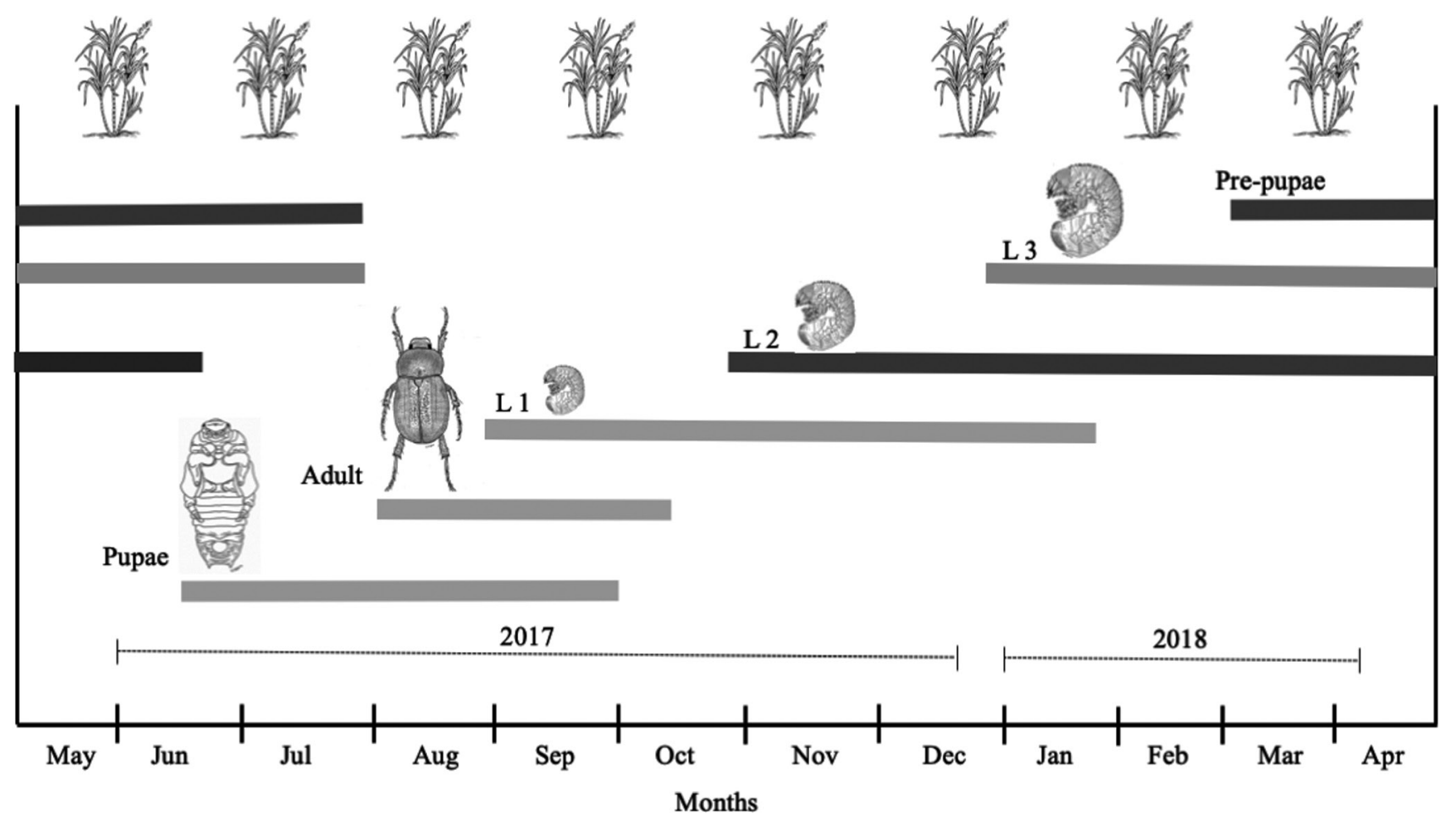

Figure 1. Developmental stages of Plectris aliena observed, throughout the year, in sugarcane crop in the municipality Deodápolis, MS, Brazil.

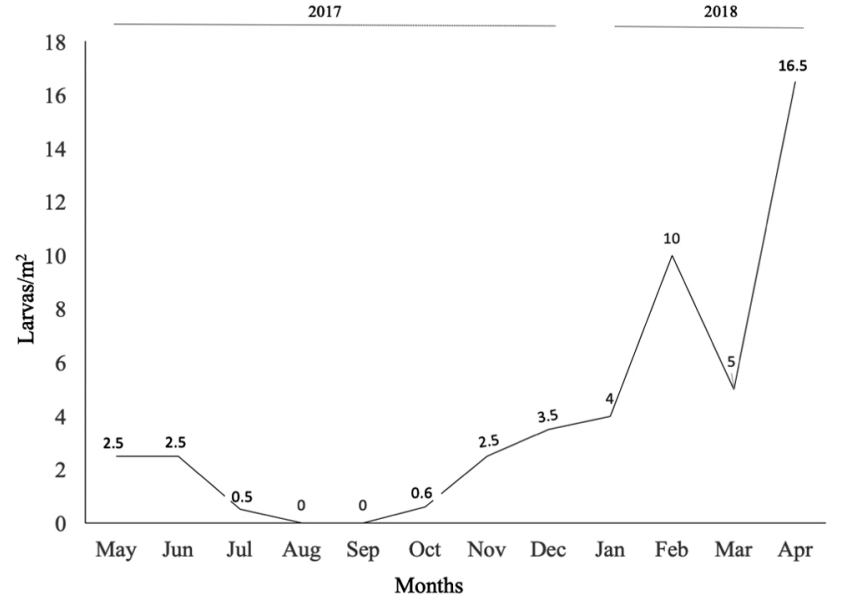

Figure 2. Average monthly number of Plectris aliena larvae sampled in the soil of the sugarcane crop, during the years 2017 and 2018 in the municipality of Deodápolis, MS, Brazil.

larvae (50 belonging to first instar, 190 to second instar, and 710 third instar larvae) and three pupae. In the light traps a total of 102 adult males and a single female were collected in the months of August $(n=10)$, September $(n=40)$, and October $(n=52)$ of 2017.

Adults were observed in the field from July to October 2017 (Fig. 1), while from September to January the first instar larvae were found in the soil profile. The second and third instar larvae began to appear in November and December 2017, respectively. The second instar larvae remained in soil until mid-June and the third instar until July of the following year, while pupae were found in the soil from June to September 2017 (Fig. 1).

The highest larval densities of $P$. aliena were observed in February (10 larvae $\left./ \mathrm{m}^{2}\right)$, March (5 larvae $/ \mathrm{m}^{2}$ ) and April
(16.5 larvae $\left./ \mathrm{m}^{2}\right)$ in 2018. Whereas between May and November 2017, larval densities were relatively low, or even null (Fig. 2).

Plectris aliena was identified by the following diagnostic features. Adults $(\mathrm{N}=21)$ with body length: 8-12 mm; width: 4-6 mm; elongated body, uniform opaque light reddish brown color, sometimes lighter in color than pronotum. Dense and short white hairs cover the head, pronotum, and elytra, abundant on the head, more dispersed in the elytra (Fig. 3A-C). The clypeus has rounded margin, antenna with 10 antennomeres, the three distal form the club of lamellae. The average length of lamellae is $1.43 \pm 0.01 \mathrm{~mm}(1.24-1.72 \mathrm{~mm})$ in males, whereas in females are $1.0 \mathrm{~mm}$. The protibiae are tridentate, with basal tooth more prominent in females; metatibiae with two spurs, apparently smaller in males (Figs. 3D, E). The tarsal claws of the anterior legs are $0.69 \pm 0.01 \mathrm{~mm}$ long and are significantly smaller $(p<0.05)$ than the meso $(1.09 \pm 0.01 \mathrm{~mm})$ and metathoracic claws $(1.09 \pm 0.01 \mathrm{~mm})$; metatarsomere $\mathrm{I}$ is $2 \frac{1}{2} 2-3$ longer than metatarsomere II. The aedeagus has dense, long setae on apical outer margin of the paramere.

The larvae (Fig. 4A) has cream-colored body, with yellowish orange head and legs. The third instar $(\mathrm{N}=30)$ (length average $29.85 \pm 1.30 \mathrm{~mm}(20-34 \mathrm{~mm}$ min. and max. length, respectively)) exhibit trapezoidal epipharynx; narrow and elongated jaws (Fig. 4B), labrum with two transverse carinae (Fig. 4B). Their raster has palidia, formed by two divergent rows of double pali, which are widely divergent in the posterior part (Fig. 4C).

Pupae $(\mathrm{N}=3)$ with $19 \pm 0.88 \mathrm{~mm}$ length and $9 \pm 0.57 \mathrm{~mm}$ width; elongated and oval body shape; dark yellowish orange in color; antenna, labrum and discernible palps; and very visible compound eyes. 


\section{DISCUSSION}

The occurrence of $P$. aliena in the field and the seasonal distribution of immature and adult stages in the sugarcane field evidences that the insect has a univoltine cycle. The population dynamics of $P$. aliena found in this study synchronizes its biological phases with the rainfall in the region, with a predominance of adult flights in August to October, similar to what was recorded by Coutinho et al. [2020] in the municipality of Nova Andradina, Mato Grosso do Sul state (Brazil). Oliveira \& Frizzas (2017) studied the bioecological characteristics of Phyllophaga capillata (Blanchard) (Melolonthidae: Melolonthinae: Melolonthini), an important soil pest of the soybean crops in Central Brazil, and also verified that this species synchronizes third instar larvae and active adults with the rainy season (October-March) in that region. The same happens with P. cuyabana, also a soybean pest in Midwestern Brazil. Oliveira (2008) found that the beginning of the adult flights of this species occur from September to November, with peak activity in October, usually after a rain. With regard on the dynamics of $P$. aliena immatures in the field (Fig. 2), the period in which second and third instar larvae (November until July of the following year), were found in the soil profile is similar to that recorded by Coutinho et al. [2020].

The low or null population density of larvae recorded from August to October (Figs. 1, 2) matches with the appearance of pupae and adults in the soil and light traps. Coutinho et al. [2020] found that P. aliena, when reach-
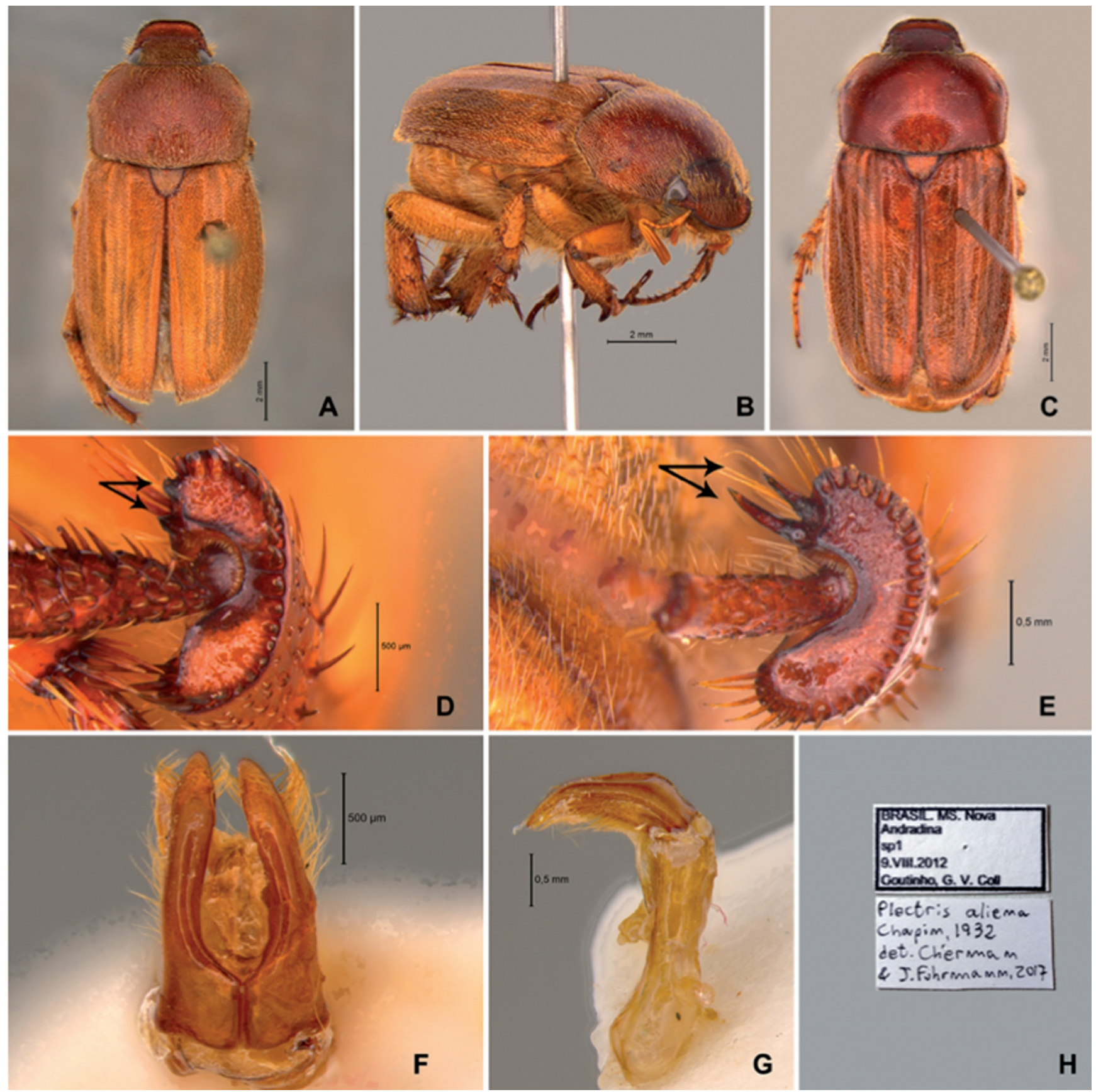

Figure 3. Plectris aliena Chapin, 1934 morphology in adults. Male habitus (A) and frontolateral view (B); female habitus (C), metatibial apex in male (D) and female (E); and male genitalia: dorsal (F) and lateral (G) views; data labels of the series deposited at DZUP (H). Black rows indicate pair of spurs. 
ing the pre-pupa phase, build their pupal chambers for shelter and protection, and can be found up to $60 \mathrm{~cm}$ deep. Similar behavior and population oscillation have been observed in P. capillata cycle (Oliveira \& Frizzas, 2017). Plectris aliena seems to be restricted in more sandy and humid soils (Roberts, 1968; Brill et al., 2013; Brill \& Abney, 2013), and there are no evidences about its occurrence in other types of soil. The sugarcane fields of Deodápolis and close to this municipality, the sandy soil (named Latossolo Vermelho Distroférrico) predominates (EMBRAPA, 2013). Thus, the crops in these areas could be eventually affected by this species.

Although it was not possible to assess the damage caused by $P$. aliena in the studied areas, a considerable decrease in the growth of primary roots was observed during the opening of the trenches, which can be attributed to the larvae of this species due to their predominance in the samples.

The $P$. aliena adults collected in the Deodápolis areas suggest that at least the males of this species have positive phototropism for artificial light. Though, Coutinho et al. [2020] reported adults of both sexes in almost the same proportion using light traps with the same technical specifications used in this work. Our results are similar to those described by Brill \& Abney (2013) in North Carolina, USA, who also found a greater number of males captured in light traps than females. Some authors suggested that it is probably related to the behavior of the males that continue flying after the first mating to look for other females for copulation (see Chapin, 1934a and
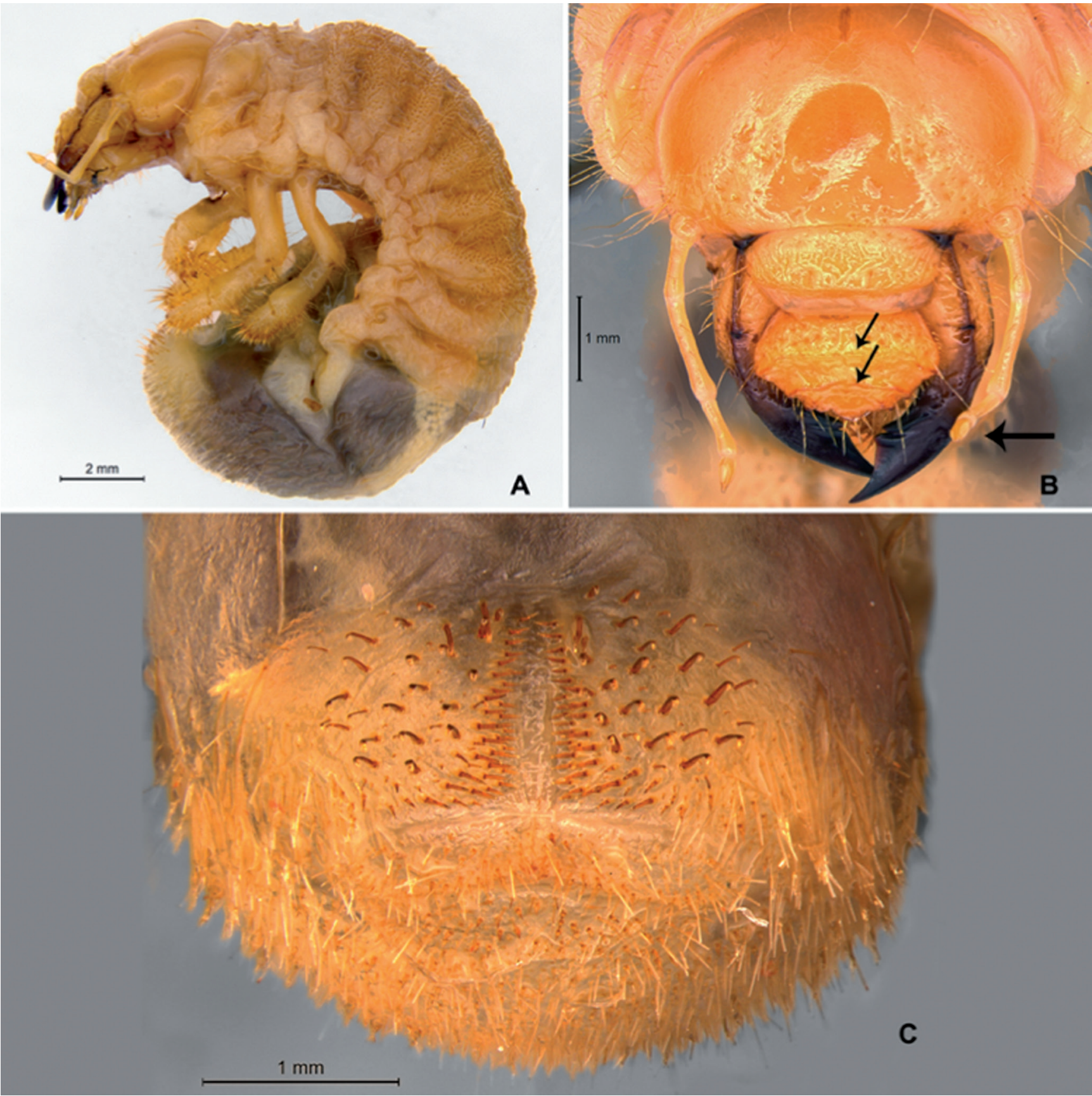

Figure 4. Plectris aliena Chapin, 1934 morphology in larvae. Body in lateral view (A); head in frontal view (B); raster (C). Black rows indicate the sensorial macula on distal antennomere and the carinae on labrum. 
Roberts, 1968). This same behavior was observed by Ferreira et al. (2016) in adults of Leucothyreus albopilosus (Melolonthidae: Rutelinae) captured in light traps in Mato Grosso do Sul, Brazil.

In this study, we verified the dimorphism of the length of the club, already pointed out by Allsopp \& Hutchinson (2018). They reported that the male club is $1.5 \mathrm{~mm}$ length, and female club is $0.8 \mathrm{~mm}$ length; which is similar to our results (average length of $1.43 \pm 0.01 \mathrm{~mm}$ in males and $1.0 \mathrm{~mm}$ in females). Thus, the difference in the club length between $P$. aliena male and female is a consistent feature for sex identification. A new dimorphic character has been noted in the present study. The size of the metatibial spurs seems to be different between males and females (Figs. 3D, E), being visibly longer in males. This discovery, although preliminary, suggests that this species has more than one dimorphic characteristic. According to Frey (1967) and Brill \& Abney (2013), the adults of $P$. aliena collected in North Carolina measure between 12-14 mm in length, which are longer than those registered in our study.

Three other species of Plectris: P. pexa (Germar), $P$. brevitarsis (Blanchard), and $P$. griseovestita (Moser) are associated with crops of economic importance in Brazil. According to Frey's (1967) key to Plectris species, Plectris aliena differs from these in the body size ( $P$. pexa 14$16 \mathrm{~mm}, P$. griseovestita $9 \mathrm{~mm}$ ) except $P$. brevitarsis $(12 \mathrm{~mm})$, and in the number of antennomeres ( $P$. pexa, $P$. brevitarsis and $P$. griseovestita have 8 antennomeres, $P$. aliena has 10 antennomeres). Plectris pexa is noticeably darker, and the bristles on the elytra form a defined pattern (Oliveira \& Hoffmann-Campo, 2001; Oliveira et al., 2004; Oliveira \& Farias 2007; Morón \& Salvadori, 2006; Valmorbida et al., 2018). One of the authors of this manuscript (MACH) suggests that the identification of $P$. brevitarsis in southern Brazil is incorrect and needs a revision which is being carried out (Cherman, unpublished). However, what is until now known as P. brevitarsis (Morón \& Salvadori, 2006) has a shiny unicolored body and elytra, dark reddish brown, thickly covered with long and abundant setae; pubescent aedeagus also in the apico-external region, but with less abundant bristles and more restricted to the distal margin of the parameres, which are longer and curved in lateral view. Plectris griseovestita is the smallest species among the four early mentioned, with elongated body, dark brown color, densely pubescent with gray hairs; and protibiae with two teeth.

\section{CONCLUSION}

A new parameter for the characterization of the secondary sexual dimorphism of $P$. aliena was found. The morphological data of adults and immatures presented in this study can help to perform accurate identification of this species in field conditions. Adults occurrence in light traps suggests that at least males are phototropic positive for artificial light. The seasonal distribution of $P$. aliena indicates that the species is univoltine, with a predominance of third instar larvae from February to
April, months in which monitoring of this species, in sugarcane areas in Mato Grosso do Sul is recommended.

\section{ACKNOWLEDGMENTS}

The authors thank for the continuous support of their member institutions: Empresa Brasileira de Pesquisa Agropecuária, Centro de Pesquisa Agropecuária do Oeste, Dourados, MS; Universidade Federal da Grande Dourados, Dourados, MS; Laboratório de Sistemática e Bioecologia de Coleoptera, Universidade Federal do Paraná, Curitiba, PR. We are grateful to the Coordenação de Aperfeiçoamento de Pessoal de Nível Superior - Brasil (CAPES) - Financial Code 001 for doctoral scholarship grant to the first author.

\section{AUTHORS' CONTRIBUTION}

The authors listed below participated effectively in the elaboration of the manuscript: E.S.G. and C.J.Á.: Experiment setup and data collection; E.S.G., C.J.Á., and M.A.C.: Tabulation, statistical analysis of data and creation of tables and figures; E.S.G. and M.A.C.: Identification of species and standardization of scientific names with their respective authors; E.S.G.: Writing the text and standardizing the rules according to the magazine; E.S.G., C.J.Á., and M.A.C.: Revision of the text and addition of significant parts.

\section{REFERENCES}

Allsopp, P.G. \& Hutchinson, P.M. 2018. The exotic whitegrub Plectris aliena Chapin (Coleoptera: Scarabaeidae: Melolonthinae) is more widely distributed in Australia than previously thought. Australian Entomologist, 45(1): 1-6.

Alvares, C.A.; Stape, J.L.; Sentelhas, P.C. \& Goncalves, J.L.M. 2013: Modeling monthly mean air temperature for Brazil. Theoretical and Applied Climatology, 113: 407-427.

Arrigoni, E.B. 1999. Pragas diversas em cana crua. In: Dinardo-Miranda, L.L.; Rossetto, R. \& Stupiello, J.P. (Orgs.). Semana da Cana-de-Açúcar de Piracicaba, 4a. Anais. Piracibaca, STAB. p. 38-39.

Ávila, C.J. \& Santos, V. 2009. Corós associados ao sistema plantio direto no Estado de Mato Grosso do Sul. Dourados, EMBRAPA Agropecuária Oeste. 32p. (Documento 101).

Böving, A.G. 1936. Description of the larva of Plectris aliena Chapin and explanation of new terms applied to the epipharynx and raster. Proceedings of the Entomological Society of Washington, 38: 169-185.

Brill, L.N. \& Abney, M.R. 2013. Plectris aliena (Coleoptera: Scarabaeidae): A New Invasive Soil Pest in North Carolina Agro-Ecosystems. Journal of Integrated Pest Management, 4: 1-8.

Brill, N.L.; Osborne, J. \& Abney, M.R. 2013. A spatial ecology study on the effects of field conditions and crop rotation on the incidence of Plectris aliena Chapin (Coleoptera: Scarabaeidae) grub damage to sweetpotato roots. Environmental Entomology, 42(5): 1046-1051.

Chapin, E. 1934a. An apparently new scarab beetle (Coleoptera) now established at Charleston, South Carolina. Proceedings of the Biological Society of Washington, 47: 33-36. 
Chapin, E. 1934b. The known distribution and habits of Plectris aliena Chapin. Journal of Economic Entomology, 27(3): 721-722.

Cherman, M.A. \& Morón, M.A. 2014. Validación de la familia Melolonthidae Leach, 1819 (Coleoptera: Scarabaeoidea). Acta Zoológica Mexicana (Nueva Serie), 30(1): 201-220.

Cherman, M.A.; Guedes, J.V.C.; Morón, M.A.; Dal Prá, E. \& Bigolin, M. 2013. White grubs (Coleoptera: Melolonthidae) in the "Planalto Region" Rio Grande do Sul state, Brazil: Key for identification, species richness and distribution. Revista Brasileira de Entomologia, 57(3): 271-278.

Companhia Nacional de Abastecimento (CONAB). 2020. Boletim da Safra de Cana-de-Açúcar: segundo levantamento, agosto 2020 - safra 2020/2021. Brasília, Companhia Nacional de Abastecimento, p. 1-64. Available: https://www.conab.gov.br/infoagro/safras/cana/boletim-da-safra-decana-de-acucar. Access: 02/10/2020.

Coutinho, G.V.; Gomes, E.S.; Ávila, C.J.; Silva, I.F.; Costa, E.N. \& Cherman, M.A. 2020. First accurate record of Plectris aliena Chapin (Coleoptera: Melolonthidae: Melolonthinae) in South America, biology and root consumption in sugarcane crops of Mato Grosso do Sul State, Brazil. Scientia Agricola (in press).

Empresa Brasileira de Pesquisa Agropecuária (EMBRAPA). 2013. Sistema brasileiro de classificação de solos. 3. ed. Brasília, EMBRAPA. 353p.

Endrödi, S. 1966. Monographie der Dynastinae (Coleoptera: Lamellicornia). Teil I Entomologische Abhandlungen, Dresden, 33: 1-457.

Ferreira, K.R.; Gomes, E.S. \& Rodrigues, S.R. 2016. Biological aspects and mating behavior of Leucothyreus albopilosus (Coleoptera: Scarabaeidae). Revista de Biologia Tropical, 64(2): 547-557.

Frey, G. 1967. Die gattung Plectris (Philochlaenia) (Coleoptera Melolonthinae). Entomologische Arbeiten aus dem museum G. Frey, 18: 1-136.

Gallo, D.; Nakano, 0.; Silveira Neto, S.; Carvalho, R.P.L.; Batista, G.C.; Berti Filho, E.; Parra, J.R.P.; Zucchi, R.A.; Alves, S.B.; Vendramin, J.D.; Marchini, I.C.; Lopes, J.R.S. \& Omoto, C. 2002. Entomologia Agrícola. Piracicaba, FEALQ. 920p.

Gassen, D.N. 1999. Manejo de Diloboderus abderus em lavouras e pastagens no Sul do Brasil. In: Reunião Latino-Americana de Scarabaeoidologia, 4a Viçosa. Memórias. Londrina, EMBRAPA Soja. p. 113-122.

Instituto Brasileiro de Geografia e Estatística (IBGE). 2019. Instituto Brasileiro de Geografia e Estatística. Available: https://www.ibge.gov.br/cidades-e estados/ms/deodapolis.html. Access: 02/10/2020.

Lucchesi, A.A. 1995. Processos fisiológicos da cultura da cana-de-açúcar (Saccharum spp.). Boletim Tecnico ESALQ/CENA, Piracicaba, n. 7, p. 1-50.

Morón, M.A. 1997. White grubs (Coleoptera: Melolonthidae: Phyllophaga Harris) in Mexico and Central America. A brief review. Trends in Entomology, 1: 117-128.
Morón, M.A. 2004. Melolontídeos edafícolas. In: Salvadori, J.R.; Ávila C.J. \& Silva, M.T.B. (Eds.). Pragas de solo no Brasil. Passo Fundo: EMBRAPA Trigo. Dourados, EMBRAPA Agropecuária 0este; FUNDACEP FECOTRIGO, Cruz Alta. p. 41-68.

Morón, M.A. \& Salvadori, J.R. 2006. The third-stage larva and pupa of Demodema brevitarsis (Blanchard) (Coleoptera: Scarabaeidae: Melolonthinae) from southern Brazil. Proceedings of the Entomological Society of Washington, 108: 511-518.

Oliveira, C.M. 2008. Biologia de campo de Phyllophaga capillata (Blanchard) (Coleoptera: Melolonthidae) em soja no Cerrado. In: Congresso Brasileiro de Entomologia, 22․ Anais. Uberlândia, UFV/UFU/EMBRAPA Milho e Sorgo Uberlândia. p. 456.

Oliveira, C.M. \& Frizzas, M.R. 2017. How climate influences the biology and behavior of Phyllophaga capillata (Coleoptera: Melolonthidae) in the Brazilian Cerrado. Austral Entomology, 58(2): 336-445. Available: https:// www.alice.cnptia.embrapa.br/bitstream/doc/1081515/1/Howclimatein fluencesthebiologyandbehaviourofPhyllophagacapillata.pdf.

Oliveira, L.J.; Farias, J.R.B. 2007. Distribuição vertical de larvas de Plectris pexa (Coleoptera: Melolonthidae), no perfil do solo. In: Reunião sulbrasileira sobre pragas de solos,10a. Anais. Dourados,EMBRAPA Agropecuária Oeste. p. 196-198. (Documentos, 88).

Oliveira, L.J. \& Hoffmann-Campo, C.B. 2001. Manejo de pragas de solo na cultura da soja. In: Anais da IV Reunião Itinerante de Fitossanidade do Instituto Biológico, V Encontro sobre doenças e pragas do cafeeiro, 2001. Instituto Biológico, Ribeirão Preto, p. 70-76.

Oliveira, L.J.; Santos, B.; Parra, J.R.P. \& Hoffmann-Campo, C.B. 2004. Coró-dasoja. In:Salvadori, J.R.; Ávila, C.J. \& Silva, M.T.B. da (Orgs.). Pragas de solo no Brasil. Passo Fundo, EMBRAPA Trigo. p. 167-190.

Parra, J.R.P. \& M.L. Haddad. 1989. Determinação do número de ínstares de insetos. Piracicaba, Fundação de Estudos Agrários Luiz de Queiroz. 49p.

Pinto, A. de S.; Botelho, P.S.M. \& Oliveira, H.N. 2009. Guia ilustrado de pragase insetos benéficos da cana-de-açúcar. Piracicaba, CP 2. 160p.

Roberts, R.J. 1968. An introduced pasture beetle, Plectris aliena Chapin (Scarabaeidae: Melolonthinae). Journal of the Australian Entomology Society, 7: 15-20.

Samson, P.; Sallam, N. \& Chandler, K. 2013. Pests of Australian sugarcane. Field guide. Indooroopilly, BSES Limited. 100p.

Santos, V. \& Ávila, C.J. 2009. Aspectos biológicos e comportamentais de Liogenys suturalis Blanchard (Coleoptera: Melolonthidae) no Mato Grosso do Sul. Neotropical Entomology, 38(6): 734-739.

Valmorbida, I.; Cherman, M.A.; Perini, C.R.; Cavallin, L.A. \& Guedes, J.V.C. 2018. Population analysis of white grubs (Coleoptera: Melolonthidae) throughout the Brazilian Pampa biome. Revista Brasileira de Entomologia, 62(4): 275-282. 